\title{
Integrating e-servqual and kano model to improve adorable projects website service quality
}

\author{
Rahma Fauziyah*, Yati Rohayati, Boby Hera Sagita \\ Department of Industrial Engineering, Telkom University, Jl. Telekomunikasi No.01, Sukapura, Kec. Dayeuhkolot, Bandung, \\ Jawa Barat, 40257, Indonesia
}

\author{
Article Information \\ Article history: \\ Received: July 02, 2019 \\ Revised: October 21, 2019 \\ Accepted: December 16, 2019 \\ Keywords: \\ E - Servqual \\ Kano Model \\ Purchasing Services \\ Website Quality Services \\ *Corresponding Author \\ Rahma Fauziyah \\ E-mail: \\ rahmafauziyah@student.telkomuniversity.ac.id
}

\begin{abstract}
A B S T R A C T
This study aims to determine the classification of attribute needs of purchasing services through the Adorable Projects website by using the integration of e-Servqual and Kano Models. The selection of these objectives is based on the low level of website usage as an online purchasing tool owned by Adorable Projects. The classification activity aims to make it easier for Adorable Projects to make improvements to the quality of its website services. Based on the results of data processing, 24 attributes in the must be the category, two attributes in the one-dimensional category, three attributes in the attractive category, and four attributes in the indifferent category. Strategy priority in developing service quality by increasing the diversity of service delivery features and product review features. The integration of e-Servqual and Kano can assist business owners in making strategic decisions related to improving the service quality.
\end{abstract}

This is an open-access article under the CC-BY-NC-SA license.

\section{INTRODUCTION}

The website as a tool in online purchasing activities provides enough convenience both in terms of customers and owners [1]. At this time, customers do not need difficulty in knowing information related to what a business provides products or services. Customers need to find information related to products or services required through the website.

The website is one of the measurement tools in ecommerce activities with page rank as the first indicator that reflects the quality of the website [2]. If the website has a poor ranking, analysis and evaluation are needed to improve visitor ratings by fixing the existing weaknesses of the site [3]. This evaluation is to increase the use of website services as a means of online purchasing [4] nd can meet customer needs. The website design must have the ability as a business tool that presents the benefits of online purchases.

Selling online allows customers to compare prices and types of products more easily and quickly. Customers consider the whole process and results of presenting the level of quality of e-commerce services [5]. The assessment of service quality from customers has a significant role in terms of levels of satisfaction, loyalty, or references to other consumers [6], [7]. 
Service quality is one of the concepts of measuring service quality in e-commerce. The service quality model of an online purchasing website service has a different viewpoint, especially in measuring quality [8]. Zeithaml's research [9] on improving website services is done by combining and synthesizing whatever is currently needed in delivering quality services to a website. This research resulted in 11 dimensions, which became the standard for evaluating service quality on the site. This dimension was then developed to improve the quality of online shopping measurements, such as the dimensions of website design, reliability, responsiveness, trust, and personalization [10], aspects of information quality, e-service quality, usefulness, e-satisfaction, and trust [2].

E-service quality is then integrated with the Kano model to get better measurement results [11], [12]. The difference between the two studies is the addition of the efficiency dimension regarding the quality measurement dimensions developed by Chang, et al. [4]. Efficiency in this dimension is related to the ease and speed of accessing service sites. The Kano model can analyze patterns of customer satisfaction with service fulfillment and product attributes [13]. Kano divides strategic decisions into must-be, one-dimensional, and attractive types.

This study aims to measure performance on websites owned by Adorable Projects. The improvement is based on the low level of website usage as a means of online purchasing on Adorable Projects. The results of these measurements can be used by the Adorable Projects to improve the quality of service that has an impact on increasing service user satisfaction.

\section{RESEARCH METHODS}

The initial stage of this research is to conduct interviews with ten respondents who know the existence of the website or have made online purchases through the website. Use of Questions aims to obtain information related to website services provided by Adorable Projects.

The results of the voice of the customer are used as the basis for preparing the e-Servqual dimension. The selection of e-Servqual dimensions is adjusted to existing research to facilitate the measurement of its parameters. Based on data processing from the initial interview, 7 dimensions were obtained that were in accordance with the conditions of the research object, namely website design [5], [14], efficiency [4], [9], responsiveness [9], [15], information quality [1], [2], fulfillment [4], [16], flexibility [9], [17], and security/privacy [9] with 33 attributes (Table 1).

The total of respondents in this study is the multiplication of the total attribute needs on the questionnaire with five [18], so that the total of respondents was 165 respondents. The final of customers used as respondents are 210 respondents. The total of respondents was obtained from the total of attributes multiplied by five and then added with 30 different respondents from the results of the pretest, the results meet valid and reliable requirements and added to the 15 respondents who also obtained from questionnaires. Large samples are used because large samples tend to provide estimates that are closer to the true value. The higher the sample size, the lower the error rate that occurs.

The first stage of processing the questionnaire is the e-Servqual questionnaire which will produce questionnaire results in the form of levels of expectation, reality, and importance. The data can be used to determine the level of quality of services provided, satisfying, or not [19]. he data is then processed to produce NKP values that are used to classify the needs attributes into strong and weak categories.

Gap : Perceived - Expected

NKP: Gap x Adjusted Importance

The second processing is the Kano Model questionnaire. The questionnaire data used are functional and dysfunctional. The two data are then processed to obtain attributes with attractive, one-dimensional, must-be, and in different categories. Attractive attributes are attributes that are not considered by consumers but can increase the level of satisfaction [20]. This additional attribute has a strategic role in increasing competitive advantage [21]. The one-dimensional attribute decreases customer satisfaction if it does not exist and can increase the level of comfort if available. Must-be is an attribute that becomes a requirement to increase customer satisfaction [22] indifferent is a complimentary attribute that does not affect the level of service quality. 
Table 1. E-servqual dimensions

\begin{tabular}{|c|c|c|c|}
\hline Dim & Definition & Need attributes & Code \\
\hline $\begin{array}{l}\text { Website } \\
\text { design }\end{array}$ & $\begin{array}{l}\text { Customer perception } \\
\text { of website appear- } \\
\text { ance }\end{array}$ & $\begin{array}{l}\text { Website appearance is designed with an attractive color } \\
\text { combination } \\
\text { The layout of the website's appearance is neatly arranged. } \\
\text { (user-friendly) when accessed via a mobile phone or personal } \\
\text { computer } \\
\text { Website visual appearance following specific themes (flash } \\
\text { sale, holiday discounts) } \\
\text { The size of the image on the main page is made proportional } \\
\text { The site looks professional with an attractive design. }\end{array}$ & $\begin{array}{l}\mathrm{WD}-3 \\
\mathrm{WD}-4 \\
\mathrm{WD}-5\end{array}$ \\
\hline Effic & $\begin{array}{l}\text { Ease and } \begin{array}{r}\text { speed in } \\
\text { accessing } \\
\text { sites }\end{array} \\
\text { service }\end{array}$ & $\begin{array}{l}\text { Ease of finding the information needed } \\
\text { The website is easy to use via a mobile phone or personal } \\
\text { computer } \\
\text { Websites can be loaded quickly } \\
\text { Websites can be loaded quickly } \\
\text { The site has a search menu (search) that can be appropriately } \\
\text { used via mobile phones or PC } \\
\text { There is a login option using links to other accounts (e-mail, } \\
\text { Facebook) }\end{array}$ & $\begin{array}{l}\mathrm{EF}-1 \\
\mathrm{EF}-2 \\
\mathrm{EF}-3 \\
\mathrm{EF}-4 \\
\mathrm{EF}-5\end{array}$ \\
\hline $\begin{array}{l}\text { Responsive- } \\
\text { ness }\end{array}$ & $\begin{array}{l}\text { Responsiveness to } \\
\text { solving problems and } \\
\text { providing responses } \\
\text { from services quickly }\end{array}$ & $\begin{array}{l}\text { Speed in responding to questions raised by customers } \\
\text { Customer service can provide solutions to problems } \\
\text { encountered } \\
\text { The rate of customer service in serving customer problems } \\
\text { Availability of 24-hour customer service } \\
\text { Live chat service availability }\end{array}$ & $\begin{array}{l}\mathrm{RE}-1 \\
\mathrm{RE}-2 \\
\mathrm{RE}-3 \\
\mathrm{RE}-4 \\
\mathrm{RE}-5\end{array}$ \\
\hline $\begin{array}{l}\text { In } \\
\text { qu }\end{array}$ & $\begin{array}{l}\text { The website can } \\
\text { provide quality infor- } \\
\text { mation according to } \\
\text { customer needs. }\end{array}$ & $\begin{array}{l}\text { Availability of review information of each product } \\
\text { Availability of characteristic product information (color, } \\
\text { size, material, weight) } \\
\text { Availability of shipping costs information from various } \\
\text { shipping service providers (JNE, JnT, POS, Tiki, GO-SEND) } \\
\text { Availability of product information related to product } \\
\text { promos } \\
\text { Availability of information regarding best-selling products }\end{array}$ & $\begin{array}{l}\mathrm{IQ}-1 \\
\mathrm{IQ}-2 \\
\mathrm{IQ}-3 \\
\mathrm{IQ}-4 \\
\mathrm{IQ}-5\end{array}$ \\
\hline Fulfil & $\begin{array}{l}\text { Includes accuracy of } \\
\text { service promises, } \\
\text { product stock avai- } \\
\text { lability, and product } \\
\text { delivery within the } \\
\text { promised time }\end{array}$ & $\begin{array}{l}\text { Punctual delivery of orders } \\
\text { On-time delivery of orders } \\
\text { Order delivery speed } \\
\text { Clarity of stock information of each product } \\
\text { Order processing speed }\end{array}$ & $\begin{array}{l}\mathrm{FU}-1 \\
\mathrm{FU}-2 \\
\mathrm{FU}-3 \\
\mathrm{FU}-4 \\
\mathrm{FU}-5\end{array}$ \\
\hline Flexibility & $\begin{array}{l}\text { Choosing payment } \\
\text { methods, shipping, } \\
\text { searching and return- } \\
\text { ing goods }\end{array}$ & $\begin{array}{l}\text { There is a more diverse selection of product delivery services } \\
\text { (JNE, J\&T, GO-SEND, Grab Delivery, COD and Pos) } \\
\text { There are a variety of payment service provider options, both } \\
\text { Debit and Credit (ATM Transfer, M-Banking, Credit Card, } \\
\text { Indomaret, Alfamart, OVO, and GO-PAY) } \\
\text { There are clear product return procedures } \\
\text { There are clear payment procedures according to payment } \\
\text { options }\end{array}$ & $\begin{array}{l}\mathrm{FE}-2 \\
\mathrm{FE}-3 \\
\mathrm{FE}-4\end{array}$ \\
\hline $\begin{array}{l}\text { Security/ } \\
\text { Privacy }\end{array}$ & $\begin{array}{l}\text { The level of } \\
\text { consumer confidence } \\
\text { in the website where } \\
\text { security and } \\
\text { information are } \\
\text { guaranteed }\end{array}$ & $\begin{array}{l}\text { The website can protect consumer transaction data } \\
\text { The site provides an encryption system via e-mail if there is } \\
\text { a login error when inputting a username and password } \\
\text { The site protects consumers' personal information } \\
\text { Website protects payment-related information (credit card } \\
\text { numbers, account numbers) }\end{array}$ & $\begin{array}{l}\text { PS }-1 \\
\text { PS }-2 \\
\text { PS }-3 \\
\text { PS }-4 \\
\end{array}$ \\
\hline
\end{tabular}


Categorizing these attributes is assisted with the help of the Kano Evaluation Table [9] and Blauth's Formula [23]. The following are the calculation steps in this study.

1. Evaluating the Kano model based on the attributes contained in the e-Servqual dimension.

2. Determine the Kano model category for each attribute using Blauth's Formula [11]

a. If (one dimensional + attractive + mustbe) $>$ (indifferent + reserve + questionable) then the grade is chosen from the maximum (one dimensional, attractive, must be)

b. If (one dimensional + attractive + mustbe) < (indifferent + reserve + questionable), the grade is chosen from the maximum of (indifferent, reserve, questionable)

c. If (one dimensional + attractive + mustbe $)=($ indifferent + reserve + questionable), then the grade chosen is the maximum among Kano model categories, namely (one dimensional, attractive, must be, indifferent, reserve, questionable).

3. Calculate the customer satisfaction coefficient (CSC) with IBT ratings. If the value is close to 1 , then the existence of the characteristics of the product/service has a major influence on customer satisfaction. Whereas for IWT assessment, if it is close to -1 the existence of product/service characteristics will give increasingly greater customer dissatisfaction. The following is the formula for calculating CSC values in this study.

$$
\begin{aligned}
& \mathrm{IBT}=\frac{A+O}{A+O+M+I} \\
& \mathrm{IWT}=\frac{M+O}{A+O+M+I}
\end{aligned}
$$

4. The final stage is to classify e-Servqual dimension attribute positions based on the Kano Model (Fig. 1)

The final results of all stages are used for the activities of integrating e-Servqual questionnaires and Kano models. This integration is to get the attributes of the needs which need to be maintained, enhanced, and prioritized its presence in the Adorable Projects website service.

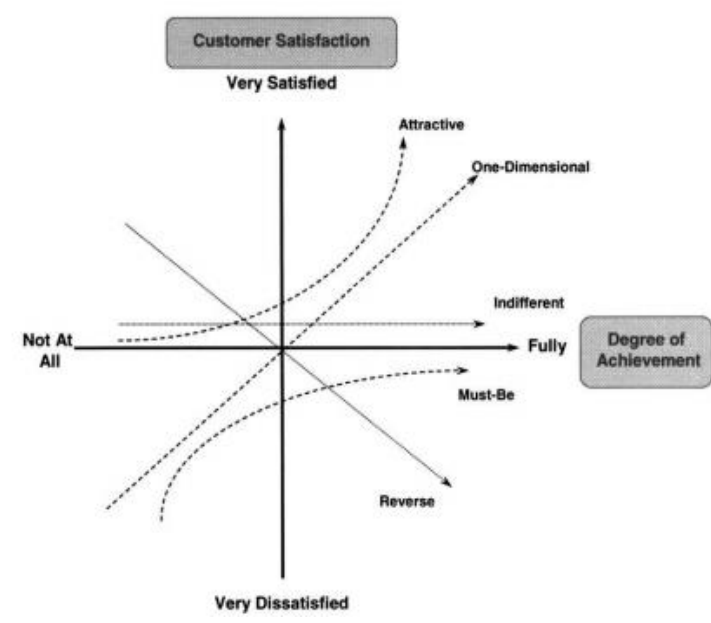

Fig. 1. Kano model [8].

Attributes with weak categories categorized as Kano must-be and one-dimensional have the opportunity to increase their presence in the service. Attributes of needs with these categories can increase customer satisfaction with website services. Attributes with strong or weak categories and attractive categories have the opportunity to prioritize their existence. Attributes with these categories can increase customer satisfaction if provided on the website service.

Attributes with a weak category with a Kano category indifferent existence can be ignored because it does not affect the increase in customer satisfaction of the service. Attributes with strong categories, must-be, one-dimensional, and in different types, their existence needs to be maintained to increase customer satisfaction with service. If the integration of e-Servqual and Kano models has been completed, then true customer needs will be obtained as a recommendation for improving purchasing services through the Adorable Projects website.

\section{RESULTS AND DISCUSSION}

The e-Servqual questionnaire data processing starts with calculating the NKP values obtained by reducing the value of the real level with expectations. The next step is to multiply the interests by the NKP value to get the Gap value. The results of these calculations will produce attributes with strong and weak categories. Attributes with strong categories will produce positive NKP values (Table 2), while attributes with weak categories will produce negative NKP values (Table 3 ). 
Table 3. Strong attributes

\begin{tabular}{cccccc}
\hline $\begin{array}{c}\text { Require } \\
\text { ments } \\
\text { attributes }\end{array}$ & $\begin{array}{c}\text { Expectati Level of } \\
\text { on level }\end{array}$ & \multicolumn{3}{c}{$\begin{array}{c}\text { Level of } \\
\text { reality }\end{array}$} & \\
& & & & & \\
import & NKP & \\
\hline WD-1 & 3.31 & 3.51 & 0.20 & 3.55 & 0.71 \\
WD-3 & 3.28 & 3.36 & 0.09 & 3.31 & 0.28 \\
WD-4 & 3.40 & 3.42 & 0.02 & 3.39 & 0.08 \\
EF-1 & 3.43 & 3.50 & 0.07 & 3.65 & 0.26 \\
EF-3 & 3.38 & 3.46 & 0.09 & 3.61 & 0.31 \\
EF-4 & 3.40 & 3.41 & 0.02 & 3.56 & 0.07 \\
RE-3 & 3.37 & 3.48 & 0.11 & 3.58 & 0.41 \\
IQ-4 & 3.40 & 3.44 & 0.03 & 3.60 & 0.12 \\
IQ-5 & 3.39 & 3.40 & 0.01 & 3.41 & 0.03 \\
FU-1 & 3.54 & 3.57 & 0.03 & 3.58 & 0.10 \\
FE-3 & 3.50 & 3.52 & 0.01 & 3.64 & 0.05 \\
FE-4 & 3.55 & 3.57 & 0.02 & 3.56 & 0.07 \\
PS-1 & 3.57 & 3.59 & 0.02 & 3.74 & 0.07 \\
PS-3 & 3.48 & 3.56 & 0.08 & 3.71 & 0.28 \\
PS-4 & 3.48 & 3.50 & 0.01 & 3.72 & 0.05 \\
\hline
\end{tabular}

Table 3. Weak attributes

\begin{tabular}{cccccc}
\hline $\begin{array}{c}\text { Requirem } \\
\text { ents } \\
\text { attributes }\end{array}$ & $\begin{array}{c}\text { Expecta } \\
\text { tion } \\
\text { level }\end{array}$ & $\begin{array}{c}\text { Level of } \\
\text { reality }\end{array}$ & Gap & $\begin{array}{c}\text { Level of } \\
\text { importa } \\
\text { nce }\end{array}$ & NKP \\
\hline WD-2 & 3.60 & 3.34 & -0.26 & 3.58 & -0.94 \\
WD-5 & 3.52 & 3.34 & -0.18 & 3.49 & -0.63 \\
EF-2 & 3.62 & 3.36 & -0.27 & 3.62 & -0.97 \\
EF-5 & 3.40 & 3.24 & -0.16 & 3.34 & -0.57 \\
RE-1 & 3.55 & 3.37 & -0.18 & 3.62 & -0.66 \\
RE-2 & 3.43 & 3.40 & -0.03 & 3.63 & -0.12 \\
RE-4 & 3.35 & 3.22 & -0.13 & 3.30 & -0.42 \\
RE-5 & 3.38 & 3.18 & -0.2 & 3.27 & -0.65 \\
IQ-1 & 3.48 & 3.32 & -0.15 & 3.58 & -0.55 \\
IQ-2 & 3.57 & 3.50 & -0.07 & 3.77 & -0.27 \\
IQ-3 & 3.40 & 3.39 & -0.02 & 3.67 & -0.07 \\
FU-2 & 3.69 & 3.51 & -0.18 & 3.65 & -0.65 \\
FU-3 & 3.70 & 3.43 & -0.26 & 3.69 & -0.98 \\
FU-4 & 3.75 & 3.46 & -0.29 & 3.69 & -1.08 \\
FU-5 & 3.71 & 3.34 & -0.37 & 3.70 & -1.37 \\
FE-1 & 3.56 & 3.39 & -0.17 & 3.67 & -0.63 \\
FE-2 & 3.56 & 3.51 & -0.04 & 3.65 & -0.16 \\
PS-2 & 3.68 & 3.49 & -0.19 & 3.62 & -0.69 \\
\hline
\end{tabular}

After the needs attributes are grouped into weak and robust attribute categories, these attributes are categorized back into the Kano model with the help of the evaluation table. The results obtained are three attributes with attractive categories, 24 attributes with must-be categories, four attributes with indifferent categories, and two attributes with one-dimensional categories. Attributes with attractive categories will be prioritized for their presence in the Adorable Projects website service.

Attributes with the must-be category on strong attributes will be maintained, while those classifyed as weak will be increased. Attributes with onedimensional categories will be increased if they are classified as weak and will be maintained if classified as strong. In contrast, attributes with indifferent categories will be ignored if classified as vulnerable and will be increased if classified as strong (Table 4).

Attributes grouped in the must-be category are 24 attributes, two attributes are included in the One Dimensional category, three attributes are in the Attractive category, and four attributes are included in the indifferent category. After each attribute has its respective category, then the CSC value is calculated again from a range of -1 to 1 , where the attribute with a positive value CSC will have a significant influence on the value of satisfaction. At the same time, the negative value will have a considerable impact on the value of dissatisfaction (Table 5).

Attributes belonging to the must-be category are attributes that serve as the basic needs of a service. This category means that if the attribute is not provided in the service, customer satisfaction will not increase. Based on the 24 attributes with the must-be type, the attribute with the highest IBT value of 0.51 , is that there are more diverse choices of product delivery services ( JNE, J\&T, GO-SEND, Grab Delivery, COD and Pos). This attribute is necessary because by providing a variety of product delivery options, customers will more easily choose a shipping service that suits their needs and desires. Providing these attributes makes consumers have a choice, which varies according to the conditions and requirements of consumers.

Furthermore, the attributes with attractive categories, which means the existence of service attributes, will increase customer satisfaction when provided and do not apply otherwise. In this category, the highest IBT value is owned by the IQ-2 attribute of 0.61 , namely the availability of review information of each product. It is considered vital because it can increase customer satisfaction if provided in the service. If the availability of review information is provided in the service, 
the customer will be more confident in the service provided by looking at the results of the customer review.

A review of quality and quantity is very influential on consumer purchasing decisions [24]. Most consumers will see a report first before deciding to buy a product. A useful review will increase high confidence in the credibility of the seller. This trust becomes an essential capital in online transactions that have a high risk and uncertainty because they do not meet direct [25].

Attributes with one-dimensional categories of existence will increase customer satisfaction if provided and will reduce customer satisfaction if not provided. The attribute value that has the highest IBT is on both of these attributes at 0.51 . Based on this, the existence of these two attributes in the service can affect customer satisfaction with the services provided.

Table 4. Evaluation and categorization of the Kano model

\begin{tabular}{|c|c|c|c|c|c|c|c|c|c|}
\hline $\begin{array}{l}\text { Attribute } \\
\text { code }\end{array}$ & $\mathbf{A}$ & $\mathbf{O}$ & $\mathbf{M}$ & $\mathbf{A}+\mathbf{O}+\mathbf{M}$ & I & $\mathbf{R}$ & $\mathbf{Q}$ & $\mathbf{I}+\mathbf{R}+\mathbf{Q}$ & Kano category \\
\hline WD-1 & 60 & 15 & 63 & 138 & 72 & 0 & 0 & 72 & Must Be \\
\hline WD-2 & 110 & 13 & 51 & 174 & 36 & 0 & 0 & 36 & Attractive \\
\hline WD-3 & 59 & 9 & 60 & 128 & 82 & 0 & 0 & 82 & Must Be \\
\hline WD-4 & 52 & 6 & 45 & 103 & 107 & 0 & 0 & 107 & Indifferent \\
\hline WD-5 & 66 & 36 & 73 & 175 & 35 & 0 & 0 & 35 & Must Be \\
\hline EF-1 & 31 & 13 & 44 & 88 & 122 & 0 & 0 & 122 & Indifferent \\
\hline $\mathrm{EF}-2$ & 66 & 39 & 74 & 179 & 31 & 0 & 0 & 31 & Must Be \\
\hline EF-3 & 30 & 11 & 47 & 88 & 122 & 0 & 0 & 122 & Indifferent \\
\hline EF-4 & 21 & 14 & 50 & 85 & 125 & 0 & 0 & 125 & Indifferent \\
\hline EF-5 & 52 & 52 & 68 & 172 & 38 & 0 & 0 & 38 & Must Be \\
\hline RE-1 & 41 & 17 & 87 & 145 & 65 & 0 & 0 & 65 & Must Be \\
\hline RE-2 & 52 & 23 & 84 & 159 & 51 & 0 & 0 & 51 & Must Be \\
\hline RE-3 & 43 & 16 & 61 & 120 & 90 & 0 & 0 & 90 & Must Be \\
\hline RE-4 & 41 & 22 & 82 & 145 & 65 & 0 & 0 & 65 & Must Be \\
\hline RE-5 & 43 & 18 & 89 & 150 & 60 & 0 & 0 & 60 & Must Be \\
\hline IQ-1 & 93 & 35 & 37 & 165 & 45 & 0 & 0 & 45 & Attractive \\
\hline IQ-2 & 57 & 49 & 60 & 166 & 44 & 0 & 0 & 44 & Attractive \\
\hline IQ-3 & 50 & 57 & 49 & 156 & 53 & 0 & 0 & 53 & One Dimensional \\
\hline IQ-4 & 33 & 38 & 69 & 140 & 70 & 0 & 0 & 70 & Must Be \\
\hline IQ-5 & 30 & 32 & 58 & 120 & 90 & 0 & 0 & 90 & Must Be \\
\hline FU-1 & 32 & 12 & 64 & 108 & 102 & 0 & 0 & 102 & Must Be \\
\hline FU-2 & 42 & 29 & 72 & 143 & 57 & 0 & 0 & 57 & Must Be \\
\hline FU-3 & 39 & 69 & 52 & 160 & 50 & 0 & 0 & 50 & One Dimensional \\
\hline FU-4 & 42 & 30 & 74 & 146 & 64 & 0 & 0 & 64 & Must Be \\
\hline FU-5 & 52 & 52 & 61 & 165 & 45 & 0 & 0 & 45 & Must Be \\
\hline FE-1 & 86 & 21 & 94 & 201 & 9 & 0 & 0 & 9 & Must Be \\
\hline FE-2 & 82 & 17 & 91 & 190 & 20 & 0 & 0 & 20 & Must Be \\
\hline FE-3 & 34 & 10 & 113 & 157 & 53 & 0 & 0 & 53 & Must Be \\
\hline FE-4 & 43 & 17 & 101 & 161 & 49 & 0 & 0 & 49 & Must Be \\
\hline PS-1 & 24 & 26 & 76 & 126 & 84 & 0 & 0 & 84 & Must Be \\
\hline PS-2 & 33 & 46 & 69 & 148 & 62 & 0 & 0 & 62 & Must Be \\
\hline PS-3 & 20 & 29 & 95 & 144 & 66 & 0 & 0 & 66 & Must Be \\
\hline PS-4 & 17 & 19 & 77 & 113 & 97 & 0 & 0 & 97 & Must Be \\
\hline
\end{tabular}


Table 5. Kano processing results

\begin{tabular}{cccccccc}
\hline $\begin{array}{c}\text { Attribute } \\
\text { code }\end{array}$ & A & O & M & I & Total & $\begin{array}{c}\text { Satisfaction } \\
\text { level }\end{array}$ & $\begin{array}{c}\text { Level of } \\
\text { dissatisfaction }\end{array}$ \\
\hline WD-1 & 60 & 15 & 63 & 72 & 210 & 0.36 & -0.37 \\
WD-2 & 110 & 13 & 51 & 36 & 210 & 0.59 & -0.30 \\
WD-3 & 59 & 9 & 60 & 82 & 210 & 0.32 & -0.33 \\
WD-4 & 52 & 6 & 45 & 107 & 210 & 0.28 & -0.24 \\
WD-5 & 66 & 36 & 73 & 35 & 210 & 0.49 & -0.52 \\
EF-1 & 31 & 13 & 44 & 122 & 210 & 0.21 & -0.27 \\
EF-2 & 66 & 39 & 74 & 31 & 210 & 0.50 & -0.54 \\
EF-3 & 30 & 11 & 47 & 122 & 210 & 0.20 & -0.28 \\
EF-4 & 21 & 14 & 50 & 125 & 210 & 0.17 & -0.30 \\
EF-5 & 52 & 52 & 68 & 38 & 210 & 0.50 & -0.57 \\
RE-1 & 41 & 17 & 87 & 65 & 210 & 0.28 & -0.50 \\
RE-2 & 52 & 23 & 84 & 51 & 210 & 0.36 & -0.51 \\
RE-3 & 43 & 16 & 61 & 90 & 210 & 0.28 & -0.37 \\
RE-4 & 41 & 22 & 82 & 65 & 210 & 0.30 & -0.50 \\
RE-5 & 43 & 18 & 89 & 60 & 210 & 0.29 & -0.51 \\
IQ-1 & 93 & 35 & 37 & 45 & 210 & 0.61 & -0.34 \\
IQ-2 & 57 & 49 & 60 & 44 & 210 & 0.50 & -0.52 \\
IQ-3 & 50 & 57 & 49 & 53 & 210 & 0.51 & -0.51 \\
IQ-4 & 33 & 38 & 69 & 70 & 210 & 0.34 & -0.51 \\
IQ-5 & 30 & 32 & 58 & 90 & 210 & 0.30 & -0.43 \\
FU-1 & 32 & 12 & 64 & 102 & 210 & 0.21 & -0.36 \\
FU-2 & 42 & 29 & 72 & 57 & 210 & 0.40 & -0.53 \\
FU-3 & 39 & 69 & 52 & 50 & 210 & 0.51 & -0.58 \\
FU-4 & 42 & 30 & 74 & 64 & 210 & 0.34 & -0.50 \\
FU-5 & 52 & 52 & 61 & 45 & 210 & 0.50 & -0.54 \\
FE-1 & 86 & 21 & 94 & 9 & 210 & 0.51 & -0.55 \\
FE-2 & 82 & 17 & 91 & 20 & 210 & 0.47 & -0.51 \\
FE-3 & 34 & 10 & 113 & 53 & 210 & 0.21 & -0.59 \\
FE-4 & 43 & 17 & 101 & 49 & 210 & 0.29 & -0.56 \\
PS-1 & 24 & 26 & 76 & 84 & 210 & 0.24 & -0.49 \\
PS-2 & 33 & 46 & 69 & 62 & 210 & 0.38 & -0.55 \\
PS-3 & 20 & 29 & 95 & 66 & 210 & 0.23 & -0.59 \\
PS-4 & 17 & 19 & 77 & 97 & 210 & 0.17 & -0.46 \\
\hline & & & & & & & \\
& & & & & \\
\end{tabular}

Attributes with indifferent categories and will not have any effect on the existence of attributes on the service. Attributes with indifferent categories in this study are the speed in responding to questions raised by customers, the ease of finding the information needed, the website can be loaded quickly, and the website has a search menu (search) that can be used properly when accessing the website through a mobile phone or personal computer. In this study, attributes with indifferent categories are included as complementary attributes in increasing customer satisfaction with the website services provided.

\section{CONCLUSION}

The integration of e-Servqual and the Kano Model has an essential role in supporting decisionmakers in determining the strategic decisions of a company. This research produces recommendations on strategies that should be carried out by Adorable Projects in improving the quality of service through the website. The approach is to provide a more diverse choice of product delivery services and the availability of information reviews (reviews) of each product, the availability of shipping cost information from various 
shipping service providers that make it easy for customers to calculate cost calculations. These three attributes have a critical role in increasing consumer confidence in an online world filled with risk of uncertainty. This research can proceed to the application of the Fuzzy Kano and AHP methods to get a better quality service development strategy.

\section{REFERENCES}

[1] H.-M. Chuang, Y.-S. Chen, C.-Y. Lin, and P.-C. Yu, "Featuring the e-service quality of online website from a varied perspective," Human-centric Comput. Inf. Sci., vol. 6, no. 1, p. 6, Dec. 2016, doi: 10.1186/s13673-016-0058-1.

[2] G. Sharma and W. Lijuan, "The effects of online service quality of e-commerce Websites on user satisfaction," Electron. Libr., vol. 33, no. 3, pp. 468-485, Jun. 2015, doi: 10.1108/EL-10-2013-0193.

[3] V. Davidavičienè and J. Tolvaišas, "Measuring quality of e-commerce web sites: Case of Lithuania," Ekon. ir Vadyb., no. 16 , pp. $723-729,2011$, available at: https://etalpykla.lituanistikadb.lt/object/L T-LDB0001:J.04 2011 1367177760859/.

[4] S.-F. Chang et al., "Measuring the Service Quality of E-Commerce and Competitive Strategies," in Web-Based Services, IGI Global, 2016, pp. 431-450 doi: 10.4018/978-1-4666-9466-8.ch019.

[5] G.-G. Lee and H.-F. Lin, "Customer perceptions of e- service quality in online shopping," Int. J. Retail Distrib. Manag., vol. 33, no. 2, pp. 161-176, Feb. 2005, doi: 10.1108/09590550510581485.

[6] S. Yang, Y. Lu, S. Gupta, and Y. Cao, "Does Context Matter? The Impact of Use Context on Mobile Internet Adoption," Int. J. Hum. Comput. Interact., vol. 28, no. 8, pp. 530-541, Aug. 2012, doi: 10.1080/10447318.2011.627299.

[7] J. W. Overby and E.-J. Lee, "The effects of utilitarian and hedonic online shopping value on consumer preference and intentions," J. Bus. Res., vol. 59, no. 1011, pp. 1160-1166, Oct. 2006, doi: 10.1016/j.jbusres.2006.03.008.

[8] L. Melián Alzola and V. Padrón Robaina, "The impact of pre- sale and post- sale factors on online purchasing satisfaction: a survey," Int. J. Qual. Reliab. Manag., vol. 27, no. 2, pp. 121-137, Jan. 2010, doi: 10.1108/02656711011014267.

[9] A. Parasuraman, V. A. Zeithaml, and A. Malhotra, "ES-QUAL: a multiple-item scale for assessing electronic service quality," J. Serv. Res., vol. 7, no. 3, pp. 213-233, Feb. 2005, doi: 10.1177/1094670504271156.

[10] N. K. Fu Tsang, M. T. H. Lai, and R. Law, "Measuring E-Service Quality for Online Travel Agencies," J. Travel Tour. Mark., vol. 27, no. 3, pp. 306-323, Apr. 2010, doi: 10.1080/10548401003744743.

[11] M. R. Rupiantoro and R. Aurachman, "Analisis Kebutuhan Pelanggan Pada Website En-zy Di Bandung Menggunakan Integrasi E-servqual Dan Model Kano," in eProceedings of Engineering, 2017, vol. 4, no. 2, pp. 1-9, available at: https://libraryeproceeding.telkomuniversit y.ac.id/index.php/engineering/article/view /1208.

[12] A. H. Manyu, A. A. Suhendra, and S. Wulandari, "Rancangan Atribut Website Bearpath Menggunakan Metode Integrasi E-servqual Dan Kano," in eProceedings of Engineering, 2019, vol. 6, no. 2, pp. 1-9, available at: https://libraryeproceeding.telkomuniversit y.ac.id/index.php/engineering/article/view /10949.

[13] N. Ratanasawadwat, "E-Service Attribute Analysis: An Application of Kano's Model," J. Econ. Bus. Manag., vol. 3, no. 11, pp. 1076-1079, 2015, doi: 10.7763/JOEBM.2015.V3.337.

[14] M. Blut, N. Chowdhry, V. Mittal, and C. Brock, "E-Service Quality: A MetaAnalytic Review," J. Retail., vol. 91, no. 4, pp. 679-700, Dec. 2015, doi: 10.1016/j.jretai.2015.05.004.

[15] L. L. Berry, "Relationship marketing of services-growing interest, emerging perspectives," J. Acad. Mark. Sci., vol. 23, no. 4, pp. 236-245, 1995, doi: $10.1177 / 009207039502300402$.

[16] V. Mummalaneni, J. (Gloria) Meng, and K. M. Elliott, "Consumer Technology Readiness and E-Service Quality in ETailing: What is the Impact on Predicting Online Purchasing?," J. Internet Commer., vol. 15, no. 4, pp. 311-331, Oct. 2016, doi: 
10.1080/15332861.2016.1237232.

[17] Y.-C. Chen, Y.-C. Shen, C. T.-Y. Lee, and F.-K. Yu, "Measuring quality variations in e-service," J. Serv. Theory Pract., vol. 27, no. 2, pp. 427-452, Mar. 2017, doi: 10.1108/JSTP-03-2015-0063.

[18] J. F. Hair, W. C. Black, B. J. Babin, and R. E. Anderson, Multivariate data analysis: Pearson new international edition. Pearson Higher Ed, 2013, available at: Google Scholar.

[19] C. Ahmadi and D. Hermawan, "E-business dan E-commerce," Penerbit Andi. Jogyakarta, pp. 47-53, 2013, available at: Google Scholar.

[20] B. Busacca and G. Padula, "Understanding the relationship between attribute performance and overall satisfaction," Mark. Intell. Plan., vol. 23, no. 6, pp. 543561, Oct. 2005, doi: 10.1108/02634500510624110.

[21] C. Basfirinci and A. Mitra, "A cross cultural investigation of airlines service quality through integration of Servqual and the Kano model," J. Air Transp. Manag., vol. 42, pp. 239-248, Jan. 2015, doi: 10.1016/j.jairtraman.2014.11.005.

[22] A. Suzianti, N. D. P. Faradilla, and S. Anjani, "Customer Preference Analysis on Fashion Online Shops using the Kano Model and Conjoint Analysis," Int. J. Technol., vol. 6, no. 5, p. 881, Dec. 2015, doi:10.14716/ijtech.v6i5.1891.

[23] K. C. Tan and T. A. Pawitra, "Integrating SERVQUAL and Kano's model into QFD for service excellence development," Manag. Serv. Qual. An Int. J., vol. 11, no. 6, pp. 418-430, 2001, doi: 10.1108/EUM0000000006520.

[24] S. Park and J. L. Nicolau, "Asymmetric effects of online consumer reviews," Ann. Tour. Res., vol. 50, pp. 67-83, Jan. 2015, doi: 10.1016/j.annals.2014.10.007.

[25] J. Lee, D.-H. Park, and I. Han, "The different effects of online consumer reviews on consumers' purchase intentions depending on trust in online shopping malls," Internet Res., vol. 21, no. 2, pp. 187-206, Jan. 2011, doi: $10.1108 / 10662241111123766$. 